Vol. 5, No. 2, 2018

https://doi.org/10.23939/eem2018.02.059

UDC 336.747.5

A. Zahorodniy

$\mathrm{PhD}$ in Economics, Professor

H. Partyn

$\mathrm{PhD}$ in Economics, Professor

Lviv Polytechnic National University

\title{
CRYPTO CURRENCY - A VIRTUAL PHENOMENON WHICH CAN DESTABILIZE FINANCIAL MARKETS
}

\begin{abstract}
The article considers the essence of a new financial instrument - the crypto currency, which is a kind of electronic money, its essence, specific features, the classification of types, advantages and disadvantages of traditional currencies, as well as prospects for further development of crypto currencies from the point of view of their impact on financial markets.

Key words: financial markets, financial instruments, electronic money, Bitcoin, crypto currency, advantages and disadvantages of the crypto currency, impact of crypto currencies on the stability of financial markets.
\end{abstract}

\section{Formulation of the problem}

The crypto currency, in comparison with other monetary instruments of the financial market, has certain advantages and disadvantages, which are caused by its virtuality, methods of emission, circulation and accounting. The problematic issues today include the question of assessing the potential of the positive and negative impact of crypto currencies and their technologies on financial markets.

\section{Analysis of recent research and publications}

Since the emergence of the first crypto currency in the financial market, this phenomenon has attracted the attention of many scholars and institutional establishments, in particular banking ones. The analytical research on the crypto currency essence conducted by the European Banking Authority [1] and the European Central Bank [2] is worth noting. In the latest research, this virtual currency is defined as a digital representation of value, not issued by a central bank, credit institution or e-money institution, which in some circumstances can be used as an alternative to money. [2, p. 4]. A lot of scientific works of Ukrainian and foreign scientists, in particular of T. Kovalchuk and K. Polyvoda are devoted to the urgent problems of the creation and use of crypto currencies, in particular their impact on financial markets, who, based on the analysis of the formation and strengthening of the crypto currency, argue that the digital currency is a virtual source of fictitious capital [3]; V. Dostov, V. Kuznietsov, P. Shust, who regard the electronic money primarily as an instrument for optimizing payment transactions [4]; O. Lobachova and V. Rodionova, who carried out the analysis of innovations, including virtual currencies, and their influence on the development of payment systems [5]; V. Lukianov, who maintains that crypto currencies are infographic-monetary symbols, quasi-substitutes of paper money [6]; H. Kartcheva, V. Kavetskyi, R. Lernatovych and S. Nikitchuk, who carried out the research on the peculiarities of the development of virtual currencies and underlying blockchain-technologies, their disadvantages, prospects and influence on the financial system [7; 8]; S. Volosovych, whose research subject was the substantiation of development prospects of the crypto currency sphere [9] and other scholars.

\section{The purpose of the research}

The purpose of the article is to analyze the influence of the crypto currency on financial markets, in particular, to identify the factors that may have a destabilizing effect on these markets. The purpose is to implement the following main tasks: to detect the main differences between the crypto currency and fiat and electronic money; to carry out the classification of the crypto currency 


\section{Zahorodniy A., Partyn H.}

on the grounds inherent in traditional money; to analyze the main advantages and disadvantages of the crypto currency; to predict the impact of crypto currency threats (destabilizing factors) on financial markets.

\section{Material and results}

The financial market is a system of economic and legal relations connected with the issue (emission), purchase and sale and circulation of financial instruments, the essence of which is legal requirements of their owners for the future receipt of certain monetary income. The combination of financial instruments (various types of a market financial product - monetary obligations, a currency, securities, options, futures, loan agreements, insurance policies, precious metals, etc.) owned by a legal or physical entity ensures the formation and use of their assets. Because of this, the terms "financial instruments" and "financial assets" are often identified, although the first concept in terms of its economic content is somewhat broader, since assets are only those means that bring their owners real income. There are a lot of classification features of financial instruments, in particular: the nature of financial obligations; priority significance; the term of financial instrument circulation in the market; the guarantee of a profitability level; the level of regulation; the level of risks; market globality and other features. According to the types of financial markets, financial instruments are divided into instruments of the currency, credit, stock, insurance markets and precious metals market (see Table 1) [10, p. 296-297, 649-650].

Table 1

\section{Types of financial markets and financial instruments inherent in them}

\begin{tabular}{|l|l|}
\hline \multicolumn{1}{|c|}{ Types of financial markets } & \multicolumn{1}{c|}{ Types of financial instruments } \\
\hline Currency market & $\begin{array}{c}\text { Foreign currency, account documents in the foreign } \\
\text { currency, certain types of securities servicing this market }\end{array}$ \\
\hline Monetary market & Money and account documents of the monetary market \\
\hline Stock market & Securities and derivatives \\
\hline Insurance market & \begin{tabular}{l} 
Insurance and reinsurance services \\
\hline Precious metals market
\end{tabular} \\
$\begin{array}{l}\text { Precious metals (gold, silver and individual metals of } \\
\text { iridio-platinum group-payer, palladium, iridium, osmium and } \\
\text { others), which form part of state's currency reserves }\end{array}$ \\
\hline
\end{tabular}

It can be concluded from the information given in Table 1 that each of the financial markets and each of the financial instruments (types of a market financial product) has a common feature monetary measurement or monetary value. Therefore, the financial market is directly related to money circulation and money (currency) has a significant impact on its functioning.

In the process of evolutionary development, money has passed three most important stages:

commodity money that was related to barter exchange;

full value money when mostly gold or silver ingots or coins played the role of money;

fiat (fiduciary, loan or fiat) money, the nominal value of which is determined, established and guaranteed by the state, and this value does not depend on the cost of the metal from which it is made. Today, most paper money is fiat, which is not secured money (has nothing but trust to the state).
The kind of fiat money is electronic money a conventional name of the money used in electronic banking services. Electronic money circulates without using paper (banknotes) or metal (coins) bearers, but through the introduction of computer technology and modern information systems into the payment sphere. The main advantages of electronic money for remote payments are: convenience for online stores and providers, since payments are made practically instantly; competitiveness over banking, and, moreover, a postal transfer; a low risk of settlement transactions; adaptability to the remote nature of payments. Due to this, electronic money is characterized as a framework technology, which "provides necessary flexibility in the process of meeting the needs of customers and gives additional competitive advantages in comparison with cash" [4, p. 11]. Electronic money is an economical, convenient and progressive bearer of monetary functions, which significantly accelerates 
cashless payments and is an instrument for optimizing payment transactions. The main feature of electronic money is that it is used, as regulated by the normative documents of the international financial institutions (the World Bank, the European Central Bank, the Bank for International Settlements, etc.), not by central banks, but by special lending institutions (banks or authorized financial institutions) within the limits of a certain amount of traditional (fiat) money previously received from the owner, which serves as a guarantee of the issued estimated amount [10, p. 153].

At the beginning of the third millennium, a new financial phenomenon, called Bitcoin (from English Bitcoin, combining two terms: bit - a minimum unit of the computer memory and coin a coin), emerged unexpectedly on the financial market for its stakeholders. Bitcoin is:

firstly, a decentralized payment system, for the protection and operation of which cryptographic algorithms are used. In this system, transaction accounting is carried out with the help of the same name the crypto currency "Bitcoin" and the same protocol of data transfer. The system allows making payments without intermediaries banks and other payment systems. The concept of this system, in the form of a file describing the protocol and principles of work, was promulgated in 2008 by the so-called Satoshi Nakamoto, whose personality is still not established (perhaps a group of people under the pseudonym). The main feature of the Bitcoin payment system is its complete decentralization, that is, the absence of a central administrator or any of its counterparts. An electronic payment in this system is irreversible, as there is no mechanism for cancelling a confirmed transaction or forcing a currency withdrawal. No one can block (arrest) money even temporarily, except for the owner himself;

secondly, a monetary unit of the virtual (digital) currency used in the Bitcoin payment system. The code of this currency is generated by the corresponding formula as a result of complex mathematical calculations using computers. The number of possible Bitcoins is registered in the program code, and is limited (21 million coins). The additional issue of the currency is impossible. This is an advantage of Bitcoin over official world currencies, whose new emissions can be caused by their depreciation and inflation. The Bitcoin rate is determined by the ratio of demand and supply. For the abbreviated symbol of Bitcoin, the Latin letters
BTC are used. The Bitcoin graphic symbol " $\mathrm{B}$ " is included in the Unicode version 10.0. The American company "Casascius Bitcoin Mint" in 2011 began the issue of metal Bitcoin coins of various denominations. Such coins are in fact "autonomous wallets", which indicate the Bitcoin address, and their secret key is hidden under a onetime hologram.

Later on, this financial phenomenon was called the crypto currency. The emergence of this term is associated with the publication of the article about the Bitcoin payment system "Cripto currency" ("Cryptographic currency") in the Forbes journal in 2011. The anonymous developer himself (or developers themselves) of the Bitcoin payment system and the same crypto-currency, like many other authors, used the term "electronic cash" (BrE. Electronic cash). Currently, today's cryptocurrency is a virtual (digital) currency, the issue and accounting of which are based on asymmetric encryption and application of various cryptographic (i.e., secret, hidden) methods of protection. A cryptographic unit (coin) is a code generated as a result of complex mathematical calculations. The coin is protected against counterfeiting because it contains encrypted information that cannot be copied. The crypto currency is different from traditional (fiat) money in that in order for the latter to appear in an electronic account, it must first be deposited to this account in real implementation, for example, through a bank or a payment terminal. The crypto currency is emitted directly in the network, and it is not related to any traditional currency or the national currency system. The main crypto currencies have a limited total emission. The key feature of the crypto currency is the absence of any internal or external administrator. Therefore, banks, tax, judicial and other public or private bodies cannot influence the transactions of stakeholders of the payment system of such a currency. The crypto currency transfer is irreversible - nobody can cancel, block, appeal or forcedly (without a private key) make a transaction. However, the parties of agreements may voluntarily temporarily and mutually block their crypto currencies as a pledge or decide that the completion or cancellation of the transaction requires the consent of all the parties. Anyone can receive the crypto currency from the network (this procedure is called mining). This needs only computer equipment of the required power and special software. The basis of all crypto 


\section{Zahorodniy A., Partyn H.}

currencies is complex calculation of certain functions that can be easily verified by reverse mathematical actions, for example, the calculation of large prime numbers. In the process of mining, the computing device solves algorithms whose complexity is constantly increasing, and having solved, extracts a coin - a set of encrypted information. The proof of coin availability on the network is a blockchain - a kind of account (profile). The extraction of each new crypto currency unit is more difficult than the previous one, as the calculation process becomes more complicated. In addition, such a calculation involves the cost of a certain amount of electricity and computer time. The crypto currency is kept decentralized, i.e. it is distributed by electronic crypto wallets of the users $[11 ; 12 ; 13 ; 14 ; 15]$.

The classic characteristics that distinguish the crypto currency from fiat and electronic money are as follows: the use of a pseudonym (Bitcoinaddress); their extraction (mining) with the help of a computer; issue independent of the central bank; the democratic nature of a cryptosystem; displaying each transaction in an open database, which cannot be changed; minimum payment for a transaction; a high transaction speed; data retrieval, that is, the direction of computer capabilities to search for one of the millions of possible combinations of the only correct code, after which the owner obtains a crypto currency [8, p. 112].

Two centuries after the start of North American golden fevers (the end of the $18^{\text {th }}$ century - the beginning of the $19^{\text {th }}$ century), characterized by unorganized gold mining mainly in the artisanal way in newly discovered deposits, the world was gripped by the crypto currency fever, with its massive unorganized extraction (mining) of coins. The number of crypto currencies is constantly increasing. As of the beginning of 2018 (that is, 10 years after the emergence of the first virtual currency - Bitcoin), the number of crypto currencies was about 2,500 kinds. The total volume of the crypto currency market as of 01.01 .2018 amounted to 612.9 billion dollars. In 2017, the market capitalization of the crypto currency grew by 34.6 (!) times. The share of each individual crypto currency in the total volume varies significantly. The first place in this list is occupied by Bitcoin -236.7 billion (38.6 \%). The volume of the next five crypto currencies amounts totally to 236.0 billion $(38.5 \%)$ in the volume of their market, namely: Ripple -88.9 billion $(14.5 \%)$;
Ethereum - 73.1 billion (11.9\%); Bitcoin cash 42.8 billion (7.0\%); Cardano - 18.6 billion (3.0\%); Litecoin -12.6 billion ( $2.1 \%)$. All the rest of the crypto currencies own only $22.9 \%$ of the market [16].

The classification of the crypto currency is given in Table. 2.

Concerning convertibility, it is accepted to distinguish two main types of the crypto currency a convertible (open) and inconvertible (closed) virtual currency. The essence of this classification feature is a chance to convert the crypto currency into fiat money and vice versa. This convertibility is not guaranteed by any legislation, therefore, does not mean its official convertibility. By the exchange rate, crypto currencies are divided into currencies with a floating rate determined by the market currency demand and supply, and with a fixed rate set by the administrator in terms of a fiat currency or other valuables (precious metals). By centralization, crypto currencies are distinguished as centralized and decentralized. Centralized ones are emitted by the central administrator who simultaneously controls the system, establishes rules for the use of currencies, maintains a centralized payment register and can remove the currency from circulation. All inconvertible crypto currencies are centralized, while convertible ones are divided into centralized and decentralized [7, p. 25-26]. Another feature of the classification is emission limit level - the emission of a certain crypto currency is limited to a certain amount of coins, whereas others do not have such restrictions [3, p. 5].

The features of the crypto currency cause its advantages and disadvantages in comparison with traditional currencies. These aspects of the functioning of the crypto currency are considered in the works of $[5 ; 7 ; 8]$ and others. S. Volosovych in [9] carried out a SWOT analysis of virtual currency schemes, on the basis of which he concludes that this currency has its advantages, disadvantages, opportunities and threats of functioning. However, in the authors' opinion, to assess the role and prospects for the further development of such a virtual phenomenon as the crypto currency can be only through the prism of its impact on financial markets.

The potential of the positive impact of crypto currencies, their technologies and instruments on financial markets is due to the following: 
Classification of crypto currencies

\begin{tabular}{|l|l|}
\hline \multicolumn{1}{|c|}{ Classification feature } & \multicolumn{1}{c|}{ Types of crypto currencies } \\
\hline Convertibility & $\begin{array}{l}\bullet \text { convertible (open); } \\
\bullet \text { inconvertible (closed) }\end{array}$ \\
\hline Exchange rate & $\begin{array}{l}\boldsymbol{\bullet} \text { with a floating exchange rate; } \\
\boldsymbol{\bullet} \text { with a fixed exchange rate }\end{array}$ \\
\hline Centralization & $\begin{array}{l}\boldsymbol{\bullet} \text { centralized; } \\
\text { decentralized }\end{array}$ \\
\hline Emission limit level & $\begin{array}{l}\boldsymbol{\bullet} \text { limited; } \\
\boldsymbol{\bullet} \text { unlimited }\end{array}$ \\
\hline
\end{tabular}

Developed by the authors due to the information provided in [7, p. 25-26] and [3, p. 5].

a cheap, easy and fast way to make payments around the world is inherent in crypto currencies, which with some adaptation can be used in existing money transfer systems. Not without reason, the central banks of individual states (in particular, the Bank of England and the People's Bank of China) are investigating, analyzing and beginning to introduce new financial technologies, first of all, the "blockchain" technology - the main platform for crypto currency circulation, as well as nonstandard tools used in these technologies [17, p. 14] Since the need to improve the innovative tools of the national payment system is obvious, the chance of introducing the electronic hryvnia based on the "blockchain" technology, which allows creating a fundamentally new infrastructure of financial services, is also considered by the National Bank of Ukraine;

in connection with the fact that the emission limit level of many popular crypto currencies is restricted by the cryptographic method (for example, Bitcoin and Namecoin - 21 million coins, Litecoin - 84 million, Feathercoin - 336 million, Freicoin - 100 million coins, etc. [3, p. 6-7], their money supply is protected from unwarranted growth, therefore such crypto currencies are not characterized by the risk of inflation;

the exchange rate of crypto currencies, in connection with the decentralization of their functioning (independence of banking regulators), is formed solely on the basis of demand for them and their supply;

the stakeholders of the crypto currency market are rapidly forming its infrastructure organize crypto exchanges that allow exchanging in real-time one crypto currency for another or for fiat money, install cryptomats (analogs of banking terminals in which one can buy a crypto currency for cash) and other elements of infrastructure that allow buying and selling goods, buying a crypto currency, paying taxes and dividends, etc. For example, in autumn 2017 in Ukraine, where the legal status of the crypto currency is not defined, the first Bitcoin cryptomats were installed (6 in Kyiv and 2 in Kharkiv). It is expected that after testing these machines, their number will increase to 150 .

Other benefits of the crypto currency include high adaptability to the financial environment, a free access to virtual currency schemes and anonymity of transactions. All these advantages provide potential opportunities for crypto currencies, namely: high innovation potential, financial inclusiveness (i.e. an access to financial services) and competition to traditional banking business [3, p. 26].

At the same time, crypto currencies are also characterized by significant drawbacks that are considered to be threats (destabilizing factors) to financial markets. There are at least six such basic threats (see Figure).

The main threat of crypto currencies to financial markets is that they, as a product of computer programming, are not subject to legislative regulation both in individual states and in the global electronic payment system. Monetary regulators today lack real opportunities to effectively influence virtual sources of the crypto currency formation. As V. Lukianov notes: "If intergovernmental associations and state central banks (in Ukraine, the National Bank of Ukraine) have a prudential influence on the development of the electronic money, the processes of creation and issue of crypto currencies are still completely spontaneous and decentralized" [6, p. 439]. A virtual and uncontrolled crypto currency can become a major destabilizing factor in financial markets. 


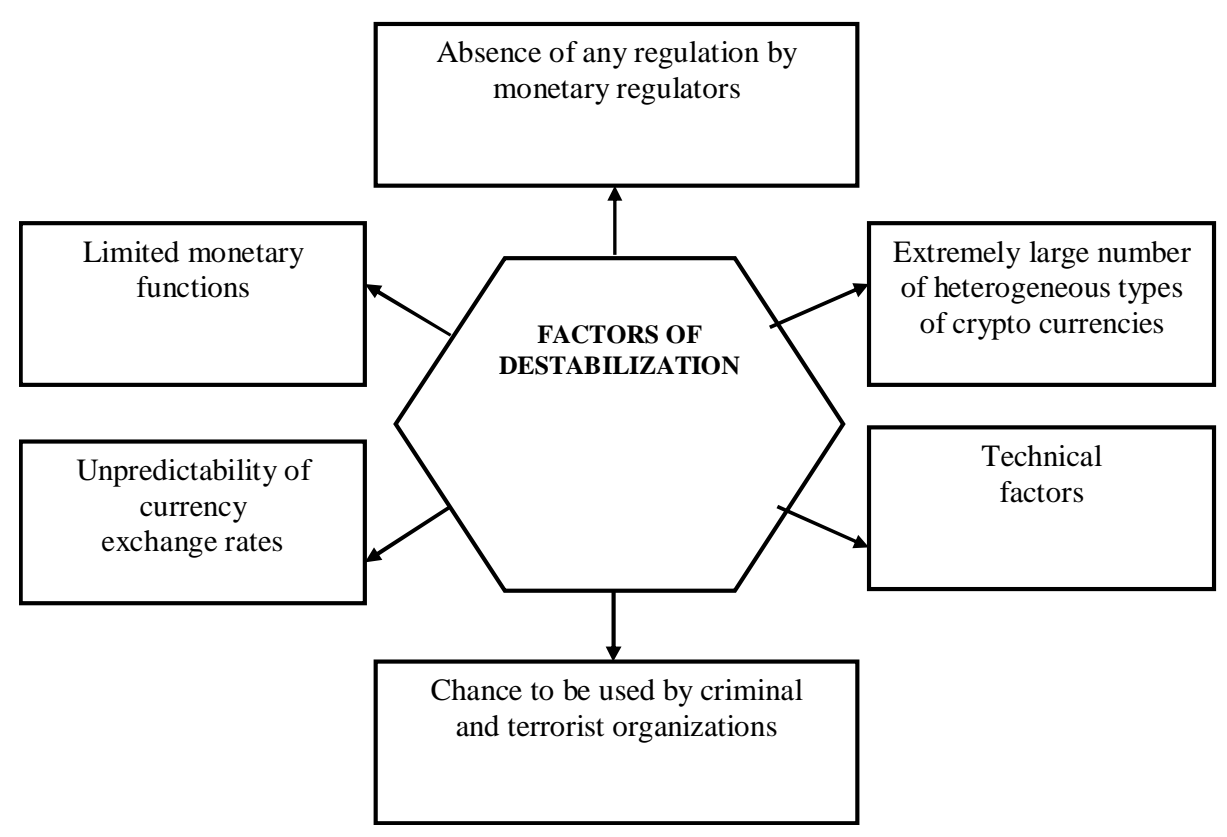

Main factors of the crypto currency - destabilizers of financial markets

The crypto-currency is characterized by the limitation of monetary functions, that is, the main features of the concrete manifestation of the essence of money. Money, in accordance with the classical theory, serves as a measure of value, a means of circulation, a means of treasure formation, a means of payment and world money. In the modern neoclassical theory, there are three functions of money - a measure of accounting, a means of accounting, a means of preserving value (accumulation) [17, p. 49]. Scientists, in particular the authors of the article [5], believe that the crypto currency is not money in the usual sense of its functions, it only "performs the functions of servicing the processes of moving funds" as an instrument of "tracking transactions, settlement and payment transactions and exchange transactions in the channels of national money and world currencies" [5, p. 7]. In the joint statement of the financial regulators of Ukraine (the National Bank of Ukraine, the National Commission on Securities and Financial Market, the National Commission for Regulation in the field of financial services) of 30.11.2017, it is argued that "the complex nature of crypto currencies does not allow them to be recognized as either money funds, or currencies, or means of payment of another state, or currency value, or electronic money, or securities, or money surrogate" [19].

The number of different crypto currencies, as already mentioned above, is extremely large.
Proceeding from the dynamics of their number in recent years, it can be predicted that by the end of 2018 or at the very beginning of next year the number of crypto currencies will exceed the figure of 3,000 . If to compare the number of crypto currencies (national and regional), as of the beginning of 2018 the number of the latter was slightly lower than 160 , and crypto currencies about 2,500, that is almost 16 times more. In addition, it is necessary to take into account the fact that crypto currencies differ a lot from each other, in particular: their issuers and emission process; methods of protection; software products that enable working with them, first of all - mining; convertibility; an exchange rate; emission limit level or its absence; other characteristics.

Practically unpredictable, and therefore very unexpected, very dynamic and powerful fluctuations in the rates of many crypto currencies (especially those in high demand) make them an unreliable and extremely risky financial instrument both for investing and speculative financial transactions. The authors absolutely agree with the scientists [3, p. 7], who argue that "the definition of the rate of crypto currencies is not subject to any logic and mathematical calculations". As an example, the authors suggest considering the dynamics (relative to the US dollar) of the first most popular and most capitalized crypto currency, also called digital gold, - Bitcoin. The history of Bitcoin since its emergence in 2008 has undergone a huge number of ups and downs. 


\section{Crypto currency - a virtual phenomenon which can destabilize financial markets}

During the first three years of its existence in the crypto currency market the Bitcoin rate against the US dollar did not exceed one dollar. 2011 was the first year of the instability of the Bitcoin exchange rate. During this year, its value increased from 1 to 91 US dollars, and then began its rapid fall. However, in February 2013, there was a tendency to increase, and in a few weeks the Bitcoin rate rose to $\$ 266$, and after November 23, its value rose to an unprecedented mark - \$1,242. Between the beginning of 2014 and the end of 2015 there was a tendency to decrease the Bitcoin rate (average balancing at the mark of $\$ 370$ per Bitcoin), after which in the early 2016 a steep drop of up to $\$ 50$ per Bitcoin was recorded. During the May of that year, the cost of this crypto currency grew rapidly, reaching the mark of $\$ 600$ at the end of the month. In the December of that year, another record of the Bitcoin rate was broken $-\$ 1,000.2017$ became the year of record growth of the Bitcoin rate, which in July of that year was already $\$ 2,900$, at the beginning of November, $\$ 7,450$, and in the middle of December approached \$19,000. Thus, in 2016 and 2017, the growth the Bitcoin rate approached 2,000 per cent per year. Anyone who understands even a bit in economic processes should come to the conclusion that such incomes are not gained without reason. Therefore, one should not reject the thoughts of those scholars and businessmen who argue that the crypto currency is a financial pyramid, because of its high volatility, a soap bubble that is going to burst sooner or later. Carefully analyzing the Bitcoin dynamics schedule in the second half of 2017 and the early 2018, one can observe the following regularity: the growth of the rate to a certain level, consolidation at this level, and in the future - a sharp fall in the exchange rate. It seems that this is done in order for the most experienced market stakeholders to be able to buy a certain number of Bitcoins at a low price, and after the Bitcoin rate is in the high, it is profitable to sell $[20 ; 21 ; 22]$. Price stability is not inherent in other crypto currencies, especially those that are in demand in the market. The rate of crypto currencies may be influenced by those crypto market stakeholders who own a large share of one or more such currencies, artificially manipulating the demand for them or their offer. This causes their unreliability as an investment tool.

Another destabilizing factor of crypto currencies for financial markets is a technical factor, which is caused by: firstly, the need for technical preconditions for the organization of crypto currency circulation, namely: computer equipment of appropriate capacity, highly skilled computer experts, an access to the Internet network and the availability of necessary computer software;

and, secondly, technical risks that may be related to a computer malfunction, in particular its hard disk, a hacker attack, a theft or hacking of a personal computer, which may result in loss of real money.

And, in the end, crypto currencies can be used by criminal and terrorist organizations to implement various types of fraudulent financial schemes and money laundering, that is, the legalization of funds received by illegal (criminal) ways - income from the shadow business, from the manufacture and sale of weapons, drugs and money counterfeit, as well as for the financing of terrorist groups and the committing terrorist acts.

Each of these factors is a definite threat to financial markets. Despite a large number of crypto currencies and their high level of capitalization, the impact of the crypto currency market on financial markets today is insignificant, since their share in monetary circulation does not exceed several percent. However, this share is gradually going up, which may increase the destabilizing effect of the crypto currency on financial markets. Therefore, every stakeholder of financial markets should take into account the possible negative impact of the crypto currency market on economic processes, and every country, in the person of its financial regulator, must determine its policy on crypto currencies and a model for regulating their market. There may be several such models: repressive involves the prohibition of crypto currencies; expected - the prohibition on crypto currency operations is absent, but there are limitations on their implementation; conservative - based on the licensing and application of instruments for regulating crypto currency transactions; liberal official recognition of crypto currencies and transactions with them [9].

\section{Conclusions}

The crypto currency, as an electronic-digital product of computer origin, which is actively winning the global financial market, is a virtual financial phenomenon, a source of fictitious capital. The growth speed of the number of crypto 


\section{Zahorodniy A., Partyn H.}

currencies, the number of their types and the rates of their capitalization is rapid, and market rates unpredictable. Crypto currencies, in view of their technologies and instruments, can have a positive effect on financial markets. At the same time, excessive negative risks can significantly exceed the potential of the positive impact. These risks are global, since the circulation of crypto currencies has no borders, and will increase with the growth of the share of the crypto currency circulation. Ukraine, in which the crypto currency market with its positive and negative factors of influence increases from year to year, should determine the model of this market regulation, legislatively approve of the official institute of such regulation, in particular, the processes of emission, mining and circulation of the crypto currency, and its functions, and also predict and develop the mechanisms of influence (state regulation) in the market of virtual currencies.

\section{References}

1. EBA Opinion on "virtual currencies" (2014). European Banking Authority.

2. Virtual currency schemes - a further analysis (2015). European Central Bank.

3. Kovalchuk, T. \& Palyvoda, K. (2014). Digital currency as a virtual source of fictitious capital. Bankivska sprava. [Banking],1-2,3-11. [in Ukrainian]

4. Dostov, V. L., Kuznetsov, V. A., \& Shust, P. M. (2013). Electronic money as a tool for optimizing payment transactions. Dengi $i$ kredit [Money and credit], 12, 7-13. [in Russian]

5. Lobacheva, E. N. \& Rodionova, V. G. (2014). Innovations in the system of electronic payments. Gumanitarnyi vesnik [Humanitarian Newsletter], 1. Retrieved from http://hmbul.bmstu.ru/catalog/ econom/hidden/160.html. [in Russian]

6. Lukyanov, V. S (2014). The emergence of cryptocurrency market in the information networking paradigm. Aktualni problemy ekonomiky [Actual problems of economics],8 (158), 436-441. [in Ukrainian]

7. Karcheva, G. T. \& Nikitchuk, S. M. (2015). Virtual innovative currencies as futures currencies. Finansovyi prostir [Financial space] ,2, 24-30. [in Ukrainian]

8. Karcheva, G., Leratovich, R., \& Kavetsky, V. (2017). Using the "blockchain" technology as a factor in improving the efficiency of the financial sector. Bankivska sprava. [Banking], 2,110-119. [in Ukrainian]

9. Volosovich, S. V. (2016). Virtual currency: globalization challenges and development prospects. Ekonomika Ukrainy [Ukraine economy], 4 (653), 68-78. [in Ukrainian]
10. Zagorodniy, A. H. \& Voznyuk, G. L. (2011). Finansovo-ekonomichnyi slovnyk [Financial and Economic Dictionary]. Lviv: Publishing House of Lviv Polytechnic National University [in Ukrainian]

11. Popov, V. (2017). Shcho take kryptovaliuta? [What is crypto currency?]. Retrieved from https://www.radiosvoboda.org/a/details/28742278.ht ml [in Ukrainian]

12. Kryptovaliuta: Zibraty po kryptakh [Cryptocurrency: Collect crypts]. (2017). Retrieved from http://www. ukrjurist.com/?artticle/1402 [in Ukrainian]

13. Bitkoin, blokchein $i$ maininh. Komu potribna kryptovaliuta i yak derzhavy yii kontroliuiut [Bitcoin, blockchain and mining. Who needs cryptocurrency and how states control it].(2017). Retrieved from https://tsn.ua/groshi/bitkoyin-blokcheyu-i-mayningkomu-potribna-kriptovalyuta-i-yak-derzhavi-yiyikontrolyuyut-1016475. html. [in Ukrainian]

14. Chto takoe kriptovaliuta [What is crypto currency?] (2017). Retrieved from http://onecoins.info/chtotakoe-kriptovalyuta.html. [in Russian]

15. Kryptovaliuta [Cryptocurrency?] (2017). Retrieved from https//uk.wikipedia.org/wiki/. [in Ukrainian]

16. Kornilov D., Zaitsev, D., Evdokimov, N., Rayzin, M., Babaev, A., \& Generalova, D. Obzor rynka kriptovaliut i ISO za 2017 god [Cryptocurrency market review and ISO for 2017] (2018). Retrieved from https://anycoin.news/2018/01/05/obzor-rynkaico-2017/. [in Russian]

17. Nikolaichuk, S. \& Pidvysotsky, R. (2016). International Research Conference "Transformation of central banks' activities". Essential. Visnyk Natsionalnoho banku Ukrainy [ Visnyk of the National Bank], 6, 6-19. [in Ukrainian]

18. Bazylevych, V. D. \& Bazylevych, K. S. (2006). Rynkova ekonomika: osnovni poniattia i katehorii [Market Economy: Key Concepts and Categories]. Kiev: Znannia [in Ukrainian]

19. Spilna zaiava finansovykh rehuliatoriv shchodo statusu kryptovaliut $v$ Ukraini [Joint statement of financial regulators on the status of cryptocurrency in Ukraine] (2017). Retrieved from https://bank.gov. ua/control/uk/publish/printable_article?art_id=5973 5329\&showTitle=true. [in Ukrainian]

20. Grafik izmeneniia kursa bitkoina za vse vremia [The schedule for changing bitcoin rate for all time] (2017). Retrieved from https://coinnet.ru/obzory/ grafik-kursa-bitcoina.html. [in Russian]

21. Istoriia bitkoina - grafik kursa stoimosti bitkoina za vse vremia [Bitcoin's history - the schedule of the rate of bitcoin cost for all time] (2017). Retrieved from http://great-word.ru/istoriya-bitkoina-grafikkursa/. [in Russian]

22. Dinamika kursa dollara SShA $k$ bitkoin (USD/BTC). [Dynamics of the US dollar to bitkoin rate (USD/BTC)] (2018). Retrieved from https://finstat. info/dinamika-kursa-dollara-ssha-k-bitkoin-usd-btc. [in Russian] 